\title{
Effect of mushroom Agaricus blazei on immune response and development of experimental cerebral malaria
}

\author{
Cynthia HVal', Fátima Brant ${ }^{1,2}$, Aline S Miranda², Flávia G Rodrigues ${ }^{1}$, Bruno C L Oliveira', Elândia A Santos ${ }^{1}$, \\ Diego R R Assis ${ }^{1}$, Lísia Esper ${ }^{1,2}$, Bruno C Silva ${ }^{4}$, Milene A Rachid ${ }^{4}$, Herbert B Tanowitz ${ }^{5}$, Antônio L Teixeira², \\ Mauro M Teixeira ${ }^{1,2}$, Wiliam C B Régis ${ }^{3}$ and Fabiana S Machado ${ }^{1,2^{*}}$
}

\begin{abstract}
Background: Cerebral malaria (CM) is debilitating and sometimes fatal. Disease severity has been associated with poor treatment access, therapeutic complexity and drug resistance and, thus, alternative therapies are increasingly necessary. In this study, the effect of the administration of Agaricus blazei, a mushroom of Brazilian origin in a model of CM caused by Plasmodium berghei, strain ANKA, was investigated in mice.

Methods: C57BL/6 mice were pre-treated with aqueous extract or fractions of A. blazei, or chloroquine, infected with P. berghei ANKA and then followed by daily administration of A. blazei or chloroquine. Parasitaemia, body weight, survival and clinical signs of the disease were evaluated periodically. The concentration of pro-and anti-inflammatory cytokines, histopathology and in vitro analyses were performed.

Results: Mice treated with A. blazei aqueous extract or fraction C, that shows antioxidant activity, displayed lower parasitaemia, increased survival, reduced weight loss and protection against the development of CM. The administration of $A$. blazei resulted in reduced levels of TNF, IL-1 $\beta$ and IL- 6 production when compared to untreated $P$. berghei-infected mice. Agaricus blazei (aqueous extract or fraction C) treated infected mice displayed reduction of brain lesions. Although chloroquine treatment reduced parasitaemia, there was increased production of proinflammatory cytokines and damage in the CNS not observed with A. blazei treatment. Moreover, the in vitro pretreatment of infected erythrocytes followed by in vivo infection resulted in lower parasitaemia, increased survival, and little evidence of clinical signs of disease.
\end{abstract}

Conclusions: This study strongly suggests that the administration of A. blazei (aqueous extract or fraction C) was effective in improving the consequences of CM in mice and may provide novel therapeutic strategies.

Keywords: Agaricus blazei Murrill, Experimental cerebral malaria, Immunomodulation, Anti-malarial therapy

\section{Background}

There is a rich history of the use of natural products in the treatment of parasitic diseases, including malaria. Mushrooms have been used for nutritional and medicinal purposes since ancient times [1]. The mushroom Agaricus blazei is of Brazilian origin and has been used

\footnotetext{
*Correspondence: machadofs@icb.ufmg.br

2 Programme in Health Sciences: Infectious Diseases and Tropical Medicine, Medical School, Federal University of Minas Gerais, Belo Horizonte, MG, Brazil

Full list of author information is available at the end of the article
}

as a functional food and a popular medicine [2]. Many laboratories have investigated the effect of $A$. blazei bioactive components as an antioxidant [3-5] and as immunomodulatory agents $[6,7]$. There is increased interest in these compounds in various disease states, such as cancer [7-11], allergy [12, 13], inflammatory diseases [13, $14]$, viral and bacterial infections $[6,7,15]$, diabetes $[16$, 17] and cholesterol biosynthesis [16]. Furthermore, there has been great interest in the use of this mushroom in the treatment of leishmaniasis [18-20]. The use of this mushroom in the treatment of malaria has not been evaluated. 
Malaria, caused by Plasmodium species remains an important cause of morbidity and mortality especially in Africa, parts of Asia and Latin America. Malaria accounts for millions of deaths and many more millions are at risk. Infections caused by Plasmodium falciparum are often the most severe [21]. The most debilitating phenotype of severe malaria is a neurological syndrome known as cerebral malaria (CM) [22-24], which predominantly affects children in sub-Saharan Africa. This disease has a mortality rate around $20 \%$ and is accompanied by seizures and neurocognitive dysfunction [21, 25]. The treatment of CM in endemic areas is complicated due to lack of access and cost of drugs and the development of resistance [23, 26-29]. Additionally, as noted successful antimalarial therapy is effective in eliminating the parasite from the bloodstream, but does not prevent the development of neuronal damage [26, 28, 29].

Agaricus blazei, or some of its fractions, stimulates the immune response, including TNF and IL- 8 production by macrophages [30] and stimulates IL-1 $\beta$ and IL-6 in human monocytes and endothelial cells [6]. Studies in healthy individuals fed $A$. blazei demonstrated significant reduction in cytokine levels including TNF, IL-1 $\beta$, IL-2, IL-6, and IL-17 in human blood [31]. Blood cells obtained from patients, with inflammatory bowel disease treated with $A$. blazei had reduced levels of IL-1 $\beta$, IL-6, IL-8, MCP-1 and G-CSF when stimulated with LPS in vitro [14]. Johnson et al. [31] observed in human healthy volunteers, after oral $A$. blazei, elevated levels of, IFN- $\gamma$, IL-2, IL-4, IL-10, IL-12 and IL-17 in blood/serum.

An aqueous extract of $A$. blazei reduced the parasite infectivity, load and viability [18] in murine macrophages infected with different species of Leishmania. Additionally, Leishmania amazonensis-infected mice treated with aqueous extract of $A$. blaze $i$ displayed a reduction of the lesions size, a reduction of parasite load in the spleen and lymph nodes, an elevation of IFN- $\gamma$ and decreased IL-4 and IL-10 in the spleen and in lymphoid nodules, respectively [19]. A. blazei has also been used in the prophylaxis and treatment of Leishmania chagasi infection [20].

Herein, there is evidence that $A$. blazei has antioxidant activity and that $A$. blazei extract or a purified fraction inhibited the production of pro-inflammatory cytokines in the brain (TNF, IL-1 $\beta$ and IL-6) and spleen (IFN- $\gamma$, IL-6 and IL-17) during Plasmodium berghei (strain ANKA) infection preventing the development of severe disease. Treatment with chloroquine resulted in an increased production of most pro-inflammatory cytokines analyzed in the brain when compared to untreated-infected and $A$. blazei-treated infected mice. We also demonstrated that A. blazei and chloroquine administration decreased parasitaemia, increased survival, but $A$. blazei demonstrated greater protection against brain damage when compared with chloroquine.

\section{Methods}

Preparation of the aqueous extract and fractions purified of the mushroom Agaricus blazei

Agaricus blazei aqueous extract was prepared by mixing $5 \mathrm{~g}$ of the mushroom powder form with $50 \mathrm{~mL}$ of milli-Q water at a concentration of $1.5 \%$ (weight/volume) for a $2 \mathrm{~h}$ incubation at room temperature, followed by centrifugation at $7,800 \times g$ (Thermo Scientific Heraus Multifuge X1R) at $4{ }^{\circ} \mathrm{C}$ for $30 \mathrm{~min}$. The supernatant was obtained (crude aqueous extract) and subjected to lyophilization (Lyophilizer LIOTOP, K105) at a temperature of $-101{ }^{\circ} \mathrm{C}$ and a pressure of $23 \mathrm{mmHg}$ for $48 \mathrm{~h}$. At the end of this process a product was obtained (crude lyophilized extract). The aqueous extract underwent centrifugation at $2,000 \times g$ for $45 \mathrm{~min}$ at $4{ }^{\circ} \mathrm{C}$ using different columns (to give three fractions with different molecular weights). The samples were subjected to the same process lyophilizing as above and then it were stored at $-20{ }^{\circ} \mathrm{C}$, until use. This procedure has been patented at CT\&T/UFMG.

\section{Chemical profile}

For the determination of all chemical compounds present in $A$. blazei, the lyophilized samples were resuspended in advance at a concentration of $1 \mathrm{mg} / \mathrm{mL}$. All tests were performed in triplicate.

\section{Protein determination by the Lowry method}

Protein determinations of $A$. blazei extracts and fractions were performed with aliquots of $30 \mu \mathrm{L}$ of each sample by adding $170 \mu \mathrm{L}$ of Milli-Q water and $2.1 \mathrm{~mL}$ of biuret (Synth, Diadema, São Paulo, Brazil). After $10 \mathrm{~min}$ in the dark, $200 \mu \mathrm{L}$ of a solution of Folin-Ciocalteau (1:2) (Sigma-Aldrich, St. Louis, MO, USA) was added, samples were then homogenized by vortex (Cyclo mixer-Clay Adams) and left to stand in the dark for $1 \mathrm{~h}$. Absorbance was then measured at $750 \mathrm{~nm}$ in a spectrophotometer (Shimaduzu, UV-160A). Milli-Q water was used as a negative control following the same pattern of samples containing biuret solution and Folin-Ciocalteau solution. A calibration curve was constructed with different concentrations of bovine serum albumin (BSA) (Sigma-Aldrich, St. Louis, MO, USA) for comparison.

\section{Determination of phenolic compounds}

The determination of phenol compounds in A. blazei mushroom Fractions and extract was performed using $80 \mu \mathrm{L}$ aliquot of each sample. For analysis we added $320 \mu \mathrm{L}$ of methanol (Sigma-Aldrich, St. Louis, MO, USA), $250 \mu \mathrm{L}$ of Folin-Ciocalteau (Sigma-Aldrich, St. Louis, MO, USA), $3 \mathrm{~mL}$ of Milli-Q water and $1 \mathrm{ml}$ of 
sodium carbonate $15 \%$ (w/v) (Synth, Diadema, São Paulo, Brazil). Homogenization was performed in shaker (Cyclo mixer-Clay Adams), the samples were kept in the dark for $1 \mathrm{~h}$. Afterwards, absorbance was determined at $750 \mathrm{~nm}$ in a spectrophotometer (Shimaduzu, UV-160A). As a negative control, enzymatic reaction was used, $80 \mu \mathrm{L}$ of methanol following the same pattern of samples containing Folin-Ciocalteau reagent (Sigma-Aldrich, St. Louis, MO, USA), Milli-Q water and sodium carbonate 15 \% (w/v) (Synth, Diadema, São Paulo, Brazil). Samples were then compared to a calibration curve of different concentrations of gallic acid (Riedel-de Haën) $0.5 \mathrm{mg} /$ $\mathrm{mL}$.

\section{Determination of flavonoids}

To an aliquot of $200 \mu \mathrm{L}$ we added $800 \mu \mathrm{L}$ of ethanol, to samples and then its was diluted with $150 \mu \mathrm{L}$ of sodium carbonate $10.6 \%, 300 \mu \mathrm{L}$ of aluminum chloride in $2 \%$ methanol (all reagents from Synth, Diadema, São Paulo, Brazil), $1 \mathrm{~mL}$ of sodium hydroxide $1 \mathrm{M}$ (Merck KGaA, Darmstadt, Germany) and $1 \mathrm{~mL}$ of Milli-Q water. After 5 min of incubation, the absorbance was read at $410 \mathrm{~nm}$ in a spectrophotometer (Shimaduzu, UV-160A). As a negative control, enzymatic reaction was used, $1 \mathrm{~mL}$ of Milli-Q water, $800 \mu \mathrm{L}$ of ethanol (Synth, Diadema, São Paulo, Brazil), sodium carbonate $10.6 \%$, aluminum chloride $2 \%$ and $1 \mathrm{~mL}$ of sodium hydroxide (Sigma-Aldrich, St. Louis, MO, USA) for comparison. Subsequently, the percentage of flavonoids was calculated in the total sample weight.

\section{Determination of carbohydrates}

Samples were diluted $(50 \times)$, and $200 \mu \mathrm{L}$ aliquots stored until further use. $200 \mu \mathrm{L}$ of phenol solution (5\%) (Merck KGaA, Darmstadt, Germany) were added to the sample, followed by $1 \mathrm{ml}$ of sulfuric acid (Sigma-Aldrich, St. Louis, MO, USA). The homogenization was performed in shaker (Cyclo mixer-Clay Adams) and after $15 \mathrm{~min}$, the absorbance was read at $480 \mathrm{~nm}$ using a UV-VIS spectrophotometer (Shimaduzu, UV-160A). As a negative control we used $200 \mu \mathrm{L}$ of reaction solution, Milli-Q water, $200 \mu \mathrm{L}$ of phenol reagent and $1 \mathrm{ml}$ of sulfuric acid (all reagents from Merck KGaA, Darmstadt, Germany). A calibration curve with standard solutions of glucose was constructed for comparison and calculation of the percentage in the total sample weight.

\section{Test of antioxidant activity}

Antioxidant activity was determined by the method of DPPH (2,2-diphenyl-1-picryl-hydrazyl) (Sigma-Aldrich, St. Louis, MO, USA) proposed by Brand-Williams et al. [32]. Briefly, to $5 \mu \mathrm{L}$ of sample we added $195 \mu \mathrm{L}$ of $\mathrm{DPPH}$ solution $(60 \mu \mathrm{M})$. The absorbance reading was performed in a spectrophotometer at $515 \mathrm{~nm}$ (Varioskan Flash, Thermo Scientific) until its stabilization. The maximum antioxidant activity was calculated by converting the absorbance percentage in antioxidant activity (AA maximum) using the formula: AA maximum $(\%)=100-\{[($ Abs sample - Abs blank $) \times 100] /$ Abs control\}. The negative control was prepared with $5 \mu \mathrm{L}$ of methanol solution $(50 \%)$ and $195 \mu \mathrm{L}$ of DPPH. The decrease in absorbance represents stabilization of this free radical.

\section{Polyacrylamide gel electrophoresis}

Samples of A. blazei extract or fractions were subjected to PAGE in the presence of SDS [33]. Briefly, electrophoretic run was performed in a vertical electrophoresis containing running buffer $(0.025 \mathrm{M}$ Tris- $\mathrm{HCl}$, pH 8.3, $0.1 \% \mathrm{SDS})$ under constant voltage $(100 \mathrm{~V})$ for $3 \mathrm{~h}$ and $30 \mathrm{~min}$. After migration, the protein in the gel was stained according to the silver method staining and the gel washed with Milli-Q water five times for 5 min each wash. After $2 \mathrm{~h}$ in the pre-fixative A (solution $50 \%$ methanol and $7.5 \%$ acetic acid), there was an additional of $2 \mathrm{~h}$ incubation in pre-fixative B (solution $5 \%$ methanol and $7.5 \%$ acid acetic acid).

\section{Administration of extracts or fractions of Agaricus blazei}

Wild-type (WT) C57BL/6 females (8-10 weeks old) mice were obtained from the Animal Care Facilities of Federal University of Minas Gerais, Belo Horizonte, Brazil. C57BL/6 mice females ( $\mathrm{n}=5$ mice/group) received by gavage ( 3 days before infection) $250 \mu \mathrm{L}$ daily of crude extract or Fractions of A. blazei or chloroquinehydroxychloroquine sulfate (Aspen Pharma, Johannesburg, South Africa, antimalarial drug used as control in the experiments). Doses used were as follows: aqueous extract: 10 and $100 \mathrm{mg} / \mathrm{kg}$ of body weight; lyophilized extract: 80 and $800 \mathrm{mg} / \mathrm{kg}$ of weight; fraction A: $10 \mathrm{mg} /$ $\mathrm{kg}$ of weight; fraction B: 10, 80 and $800 \mathrm{mg} / \mathrm{kg}$ of weight; fraction C: 100 and $800 \mathrm{mg} / \mathrm{kg}$ of weight; chloroquine: $30 \mathrm{mg} / \mathrm{kg}$ of weight. Dosages were based on the weight of $25 \mathrm{~g} /$ animal. Extracts and fractions were diluted and/ or suspended in Milli-Q water in order to keep the concentration and dose similar. After pretreatment with crude extract or fractions of $A$. blazei or chloroquine for 3 days, mice were infected with $P$. berghei (strain ANKA), followed by continuous administration of $A$. blazei or chloroquine until $7 \mathrm{dpi}$. Experiments were performed on day 5 post-infection (dpi) when $P$. berghei-infected mice develop brain inflammation without motor impairment $[34,35]$. This study was carried out in strict accordance with the Brazilian Guidelines on animal work and the Guide for the Care and Use of Laboratory Animals of the National Institutes of Health. The animal ethics 
committee of the Universidade Federal de Minas Gerais CETEA/UFMG approved all experiments and procedures including euthanasia, fluid and organ removal (Permit Number: 262/11).

\section{Parasitology and experimental infection}

Blood stages of $P$. berghei constitutively expressing green fluorescent protein (P. berghei ANKA-GFP) (15cy1 clone) [24], kindly provided by Dr. Claudio Marinho (University of São Paulo), were stored in liquid nitrogen. Mice were infected intraperitoneally (i.p.) with $10^{5} \mathrm{P}$. bergheiinfected red blood cells suspended in $0.2 \mathrm{~mL}$ PBS. The percentage of parasitaemia was quantified by GFP frequency in whole blood using flow cytometry according to the methodology described by Brant et al. [22].

\section{Parasitaemia, clinical signs and liver function}

Mice were observed daily for parasitaemia, survival and clinical signs of CM (i.e. ataxia, paralysis, and coma). CM signs were evaluated using the rapid murine coma and behaviour scale (RMCBS), a protocol based on the components of the SHIRPA (SmithKline/Harwell/Imperial College/Royal Hospital/Phenotype Assessment) score [36]. The RMCBS consists of ten parameters (gait, balance, motor performance, body position, limb strength, touch scape, pinna reflex, toe pinch, aggression and grooming), and each item is scored from zero as the lowest, to two as the highest, with a maximum total score of 20. This scale is a quantitative and objective method that enables a rapid follow up of CM course. This assessment was carried out daily from day 3 dpi until day 7 dpi. For haematocrit determination at $5 \mathrm{dpi}$, blood samples were collected into heparinized capillary tubes, and centrifuged for $10 \mathrm{~min}$ in a haematocrit centrifuge (HT, São Paulo, Brazil). Liver function of $P$. berghei-infected and control mice was determined by measuring the levels of alanine aminotransferase (ALT) and aspartate aminotransferase (AST) in serum at 5 dpi using a commercially available kit following the manufacturer's protocol (Quibasa, Bioclin, Belo Horizonte, Brazil).

\section{Brain pathology and quantification of cytokines}

At 5 dpi mice were euthanized with ketamine/xylazine, the brain was carefully removed, immediately fixed in $4 \%$ buffered formalin and tissue fragment was embedded in paraffin. Tissue sections ( $4 \mu \mathrm{m}$ thick) were stained with haematoxylin and eosin (H\&E) and examined under light microscopy. Sections were captured with a digital camera (DEI-470; Optronics, Goleta, CA, USA) connected to a microscope (IX70; Olympus, Center Valley, PA, USA) with a magnification of $20 \times$. For quantification of cytokines, brains and spleens were homogenized in a PBS-buffer containing a protease-inhibitor cocktail to determine the concentrations of the cytokines IFN$\gamma$, TNF, IL-1 $\beta$, IL-6, IL-10, IL-12, IL-17 and TGF- $\beta$ by enzyme-linked immunosorbent assay (ELISA) DuoSet kits (R\&D Systems, Minneapolis, MN, USA), in accordance to the manufacturer's instructions.

\section{Treatment of infected red blood cells in vitro}

Parasitized blood was collected from $P$. berghei-infected mice displaying a 5-8 \% parasitaemia and was pretreated with a concentration of $500 \mu \mathrm{g} / \mathrm{mL}$ of $A$. blazei aqueous extract, lyophilized extract or fraction C. After $1 \mathrm{~h}$ of incubation, untreated infected red blood cells or $A$. blazei-treated infected red blood cells were centrifuged (Centrifuge 5415R, Eppendorf) in $100 \times g$ for $5 \mathrm{~min}$ at $24{ }^{\circ} \mathrm{C}$. The supernatant was discarded and PBS was added, followed by intraperitoneal inoculation in C57BL/6 mice.

\section{Statistical analysis}

Data was analysed by statistical and Graph Prism Software 4.0 (GraphPad, La Jolla, CA, USA). Results are shown as mean \pm standard error of the mean (SEM). Differences were compared by using two-tailed Student's $t$ tests with $95 \%$ confidence intervals, analysis of variance (ANOVA) or Two-way ANOVA followed by Bonferroni's corrections as needed for multiple comparisons when parametric assumptions were met. Differences between lethality curves were calculated using Log rank test. Results with a $\mathrm{P}<0.05$ were considered significant.

\section{Results}

\section{Characterization of the Agaricus blazei crude extract}

The chemical characteristics of the A. blazei crude extract were investigated. Figure 1 demonstrates that the A. blazei crude extract is rich in carbohydrates, proteins and, to a lesser extent, phenolic compounds (Fig. 1a). The protein profile ranged from 45 to $25 \mathrm{kDa}$ (Fig. 1b) and its concentration was also used as a reference for the analyses of the anti-malarial activity (based on previous studies of the microbicidal activity of $A$. blazei against Leishmania infection [18-20]. Figure 1c, shows that this extract has elevated antioxidant capacity.

\section{Administration of Agaricus blazei aqueous extract decreases parasitaemia and increases survival of Plasmodium berghei-infected mice}

Agaricus blazei aqueous extract-treated mice $(100 \mathrm{mg} /$ $\mathrm{Kg}$ ) displayed a significant decline in parasitaemia when compared with untreated mice at 6 and 7 dpi (Fig. 2a). There was increased survival $(\sim 85 \%)$ for an additional 20 days (Fig. 2b), and no clinical signs were noted (Fig. 2c). Untreated P. berghei-infected mice ( $90 \%)$ developed ataxia, loss of grip strength, progressive 


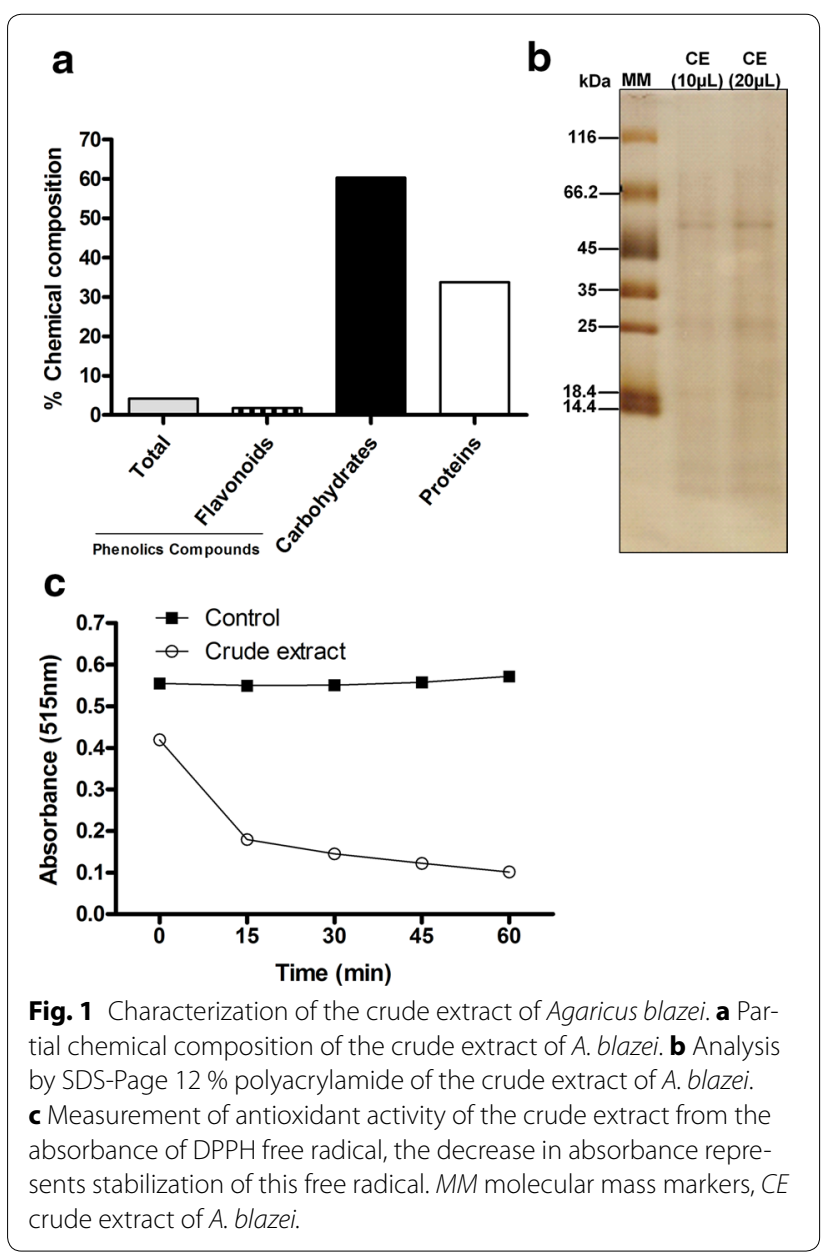

paralysis, coma, ruffled fur and significant weight loss (Fig. 2c, d) between 6 and 7 dpi. A. blazei aqueous extract-treated mice had non-significant reduction in body weight (Fig. 2d). None of the groups showed significant differences in haematocrit at 5 dpi (Fig. 2e). When A. blazei aqueous extract was administrated to infected mice at dose of $10 \mathrm{mg} / \mathrm{kg}$ the course of infection was comparable with untreated infected mice (see Additional file $1 \mathrm{~A}-\mathrm{C}$ ) indicating, that in low concentration this extract is not effective. Next, was then tested whether the A. blazei extract in lyophilized form could exert antimalarial activity since lyophilized formulations increase storage time and the product quality [37]. Administration of $80 \mathrm{mg} / \mathrm{kg}$ of $A$. blazei lyophilized extract did not confer resistance against $P$. berghei-infection (see Additional file 2A, B). However, administration of $800 \mathrm{mg} / \mathrm{kg}$ of $A$. blazei lyophilized extract to infected mice resulted in significant survival $(\sim 80 \%)$ and no visible clinical sings of CM (see Additional file 2A, B). Transaminase determinations revealed no hepatic cytotoxic effects during A. blazei administration (see Additional file 3A, B). The mushroom extract has very low toxicity in animal models $[38,39]$ and is likely safe for human at concentrations from 900 to $1,500 \mathrm{mg} /$ day for until 1 year of treatment [40-42]. Mice treated with chloroquine displayed a decline in parasitaemia and increased survival (Fig. 2).

\section{Administration of purified Agaricus blazei fraction protects against Plasmodium berghei infection}

Next was determined whether there was a specific $A$. blazei purified fraction responsible for the observed anti-malarial activity. It was found fractions $\mathrm{A}, \mathrm{B}$ and $\mathrm{C}$, which were characterized by chemical composition, protein profile and antioxidant activity (Fig. $3 \mathrm{a}-\mathrm{C}$ ), were separated by differences in MW. Fraction A had a MW greater than $10 \mathrm{kDa}$, the MW of fraction $\mathrm{B}$ was between 3 and $10 \mathrm{kDa}$, and fraction $C$ had a MW less than $3 \mathrm{kDa}$. All three fractions had large amounts of carbohydrate (73.37 \% for fraction A, $55.37 \%$ for fraction B and $56.86 \%$ for fraction C). Fractions B and $C$ contained higher levels of protein (38.11 and $37.37 \%$, respectively) and phenolic compounds (4.73 and $4.96 \%$, respectively) than fraction A (22.39\% protein and $2.12 \%$ phenolic compounds). Fraction $\mathrm{C}$ contained the lowest percentage of flavonoids $(0.81 \%)$ (Fig. 3a). The protein profile demonstrated several proteins with different MWs. However, both fractions $B$ and $C$ had proteins with MWs less than $14.4 \mathrm{kDa}$ (Fig. 3b). The high protein content of the fractions B and $\mathrm{C}$ is likely due to the presence of peptides (Fig. $3 \mathrm{~b}$ ). There were higher antioxidant activities in fractions $\mathrm{B}$ and $\mathrm{C}$, and lower activity in fraction A (Fig. 3c).

The anti-malarial activity of these three fractions was also evaluated. There were no significant differences in parasitaemia and mortality between those mice treated with fraction A $(10 \mathrm{mg} / \mathrm{kg})$ and untreated infected mice (see Additional file 4A-C), and this fraction was no longer studied. The fraction $B$ was administered at doses of 10, 80 and $800 \mathrm{mg} / \mathrm{kg}$ (see Additional file 5). It was observed that different doses of fraction B were not effective in controlling parasite replication, and treated mice died between 6 and $10 \mathrm{dpi}$, similar to untreated infected mice (see Additional file 5A, B). Next, the antimalarial activity of fraction $C$ was examined using a dose of $100 \mathrm{mg} / \mathrm{kg}$ (Fig. 3d), the same used for the aqueous extract. Mice treated with fraction $\mathrm{C}$ did not show significant differences in parasitaemia during the first $7 \mathrm{dpi}$, contrasting the results observed with aqueous $A$. blazei treatment. Despite this, fraction C-treated-mice survived more than 15 dpi ( $80 \%)$ (Fig. 3e) and did not display clinical signs (see Additional file 6A) of CM when compared to untreated infected mice. Similarly to untreated infected group, fraction C-treated-mice displayed significant weight loss (Fig. 3f). There were no significant differences in haematocrit between the groups (see Additional file 6B). 

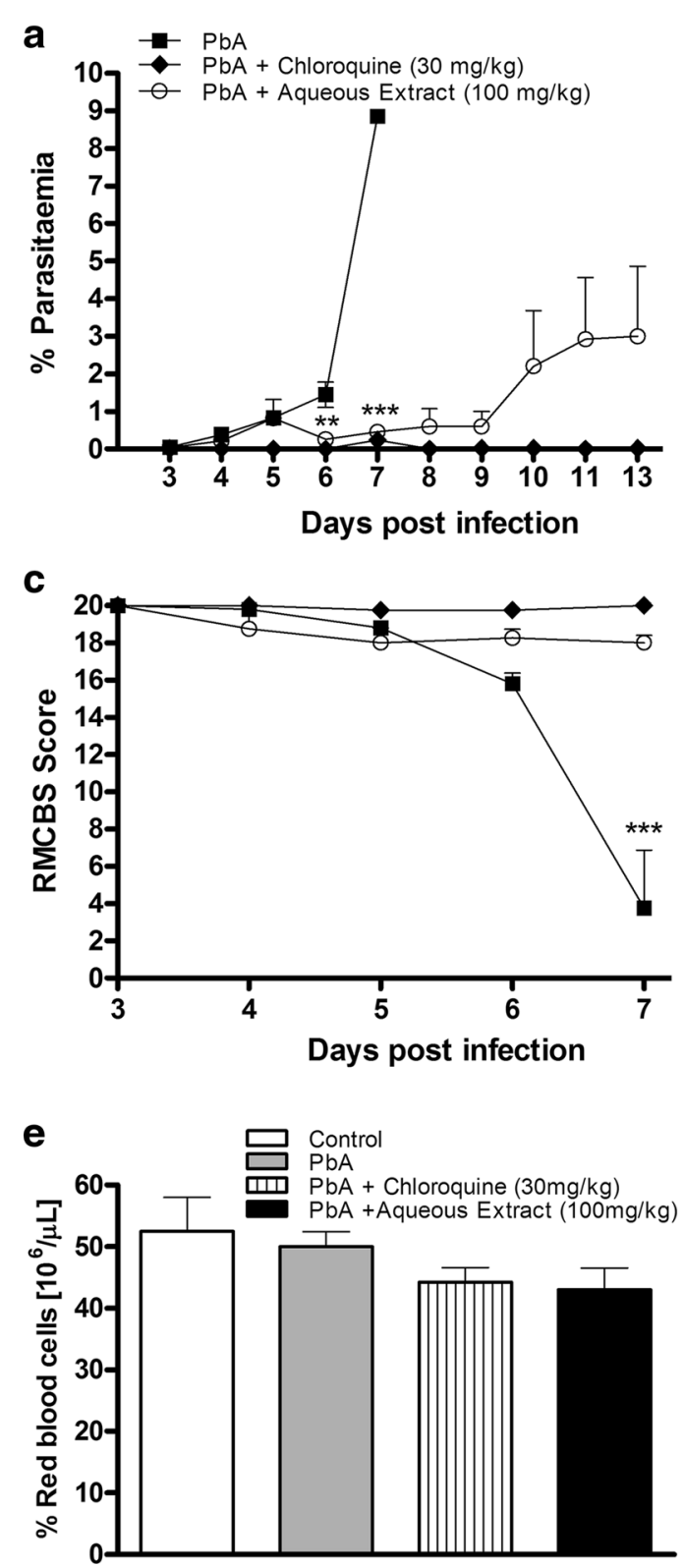

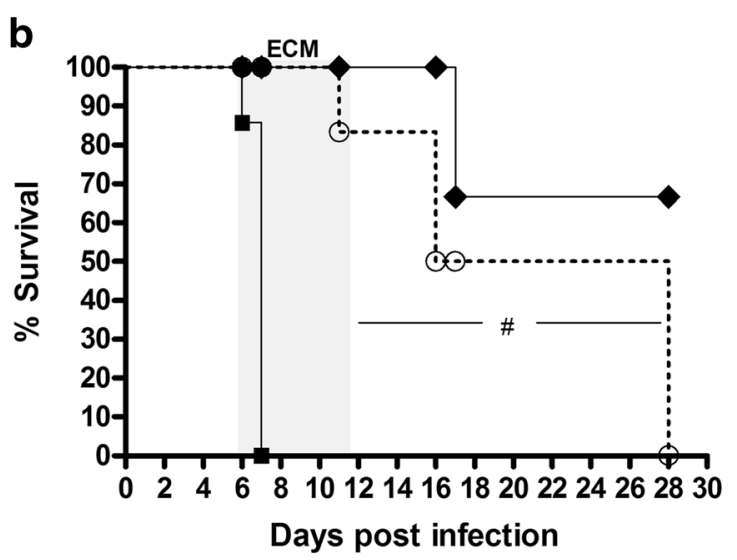

d

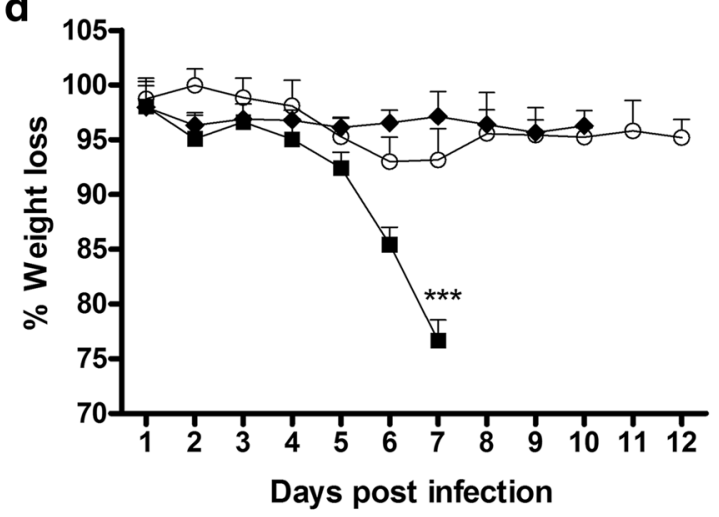

Fig. 2 Administration of aqueous extract results in the resistance of mice to Plasmodium berghei-infection. C57BL/6 mice received $100 \mathrm{mg} / \mathrm{kg}$ of A. blazei extract or chloroquine $\left(30 \mathrm{mg} / \mathrm{kg}\right.$ ) 3 days before infection, then infected with $10^{5}$ P. berghei red blood cells (pRBCs), and treated until $7 \mathrm{dpi}$. a Parasitaemia, $\mathbf{b}$ survival and $\mathbf{c}$ clinical signs of cerebral malaria assessed by the RMCBS scale and $\mathbf{d}$ body weight of untreated P. berghei-infected mice and treated with chloroquine or A. blazei aqueous extract. Neurologic signs of CM appeared on days 6-12 (shaded area), with death occurring 24-48 $\mathrm{h}$ after onset. e Haematocrit was assessed on 5th dpi in the above groups and in mice uninfected. Parasitaemia, body weight and haematocrit (\%) values are expressed as mean \pm SD of 5 mice per group. ${ }^{*} p<0.001$, log-rank test and ${ }^{* *} p<0.01$ and ${ }^{* * *} p<0.001$, ANOVA followed Bonferroni's test.

Administration of Agaricus blazei results in modulation of immune response and protection against brain damage during Plasmodium berghei infection

Infection-associated induction of pro-inflammatory cytokines such as IFN- $\gamma$, TNF and IL- $1 \beta$ poses a double-edged sword. Cytokines are essential for control of parasite growth but are also associated with tissue damage both in experimental and clinical settings. In the spleen, the levels of TNF and IL- $1 \beta$ did not change as a result of the administration of the extract. IL-12 production was significantly decreased in mice receiving aqueous extract when compared with untreated infected mice 


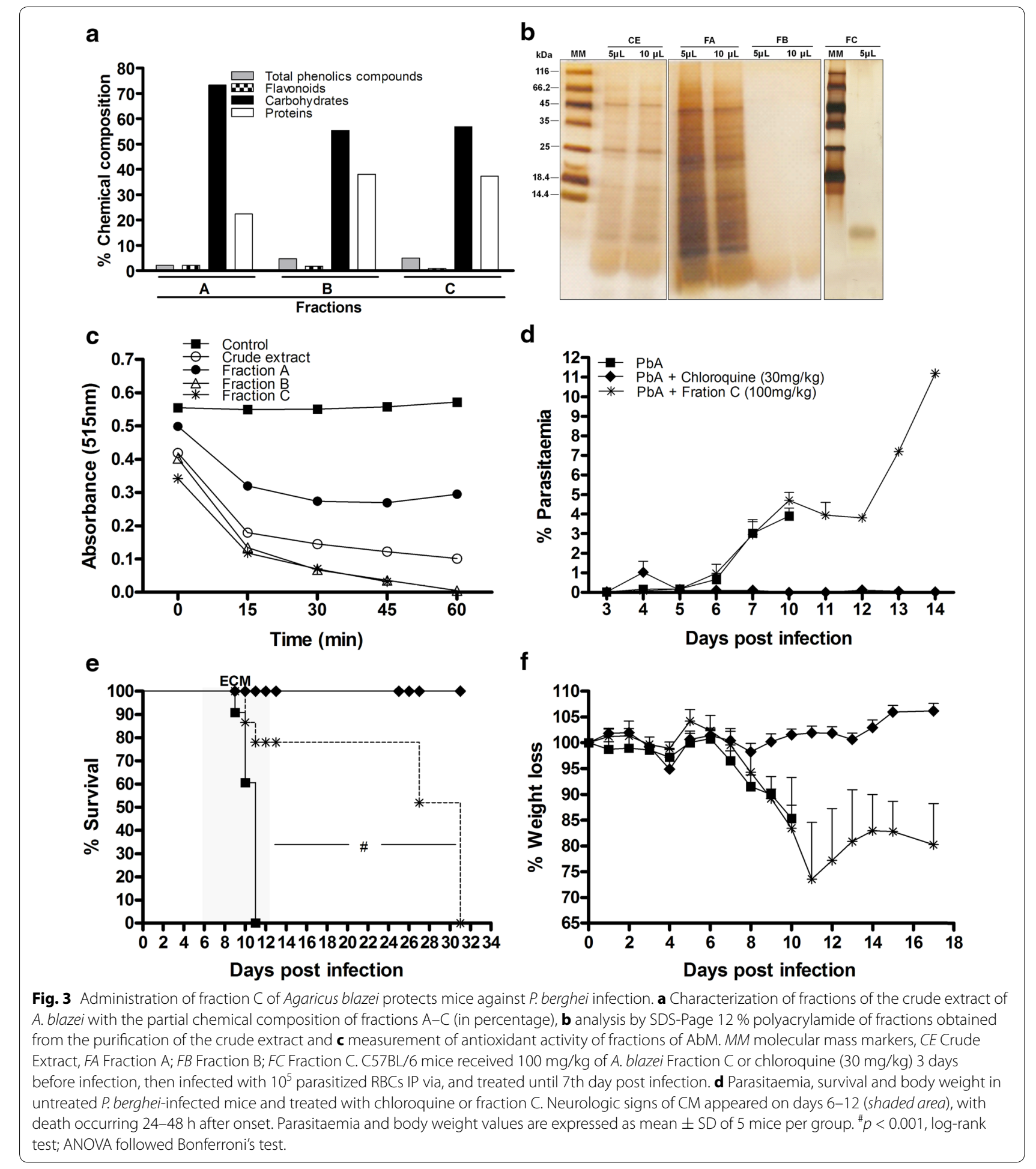

(Fig. 4a). Infected mice that received the aqueous extract or fraction $C$ displayed a significant reduction of IL-6, IL-10, IL-17, IFN- $\gamma$ and TGF- $\beta$ levels when compared with untreated infected mice. Similar results were also observed in infected mice that received the chloroquine demonstrating reduced levels of those cytokines, except for IL- 6 and TGF- $\beta$ when compared to untreatedinfected mice (Fig. 4a).

There was a significant reduction of TNF, IL-1 $\beta$ and IL- 6 levels in the brains of infected mice that received 

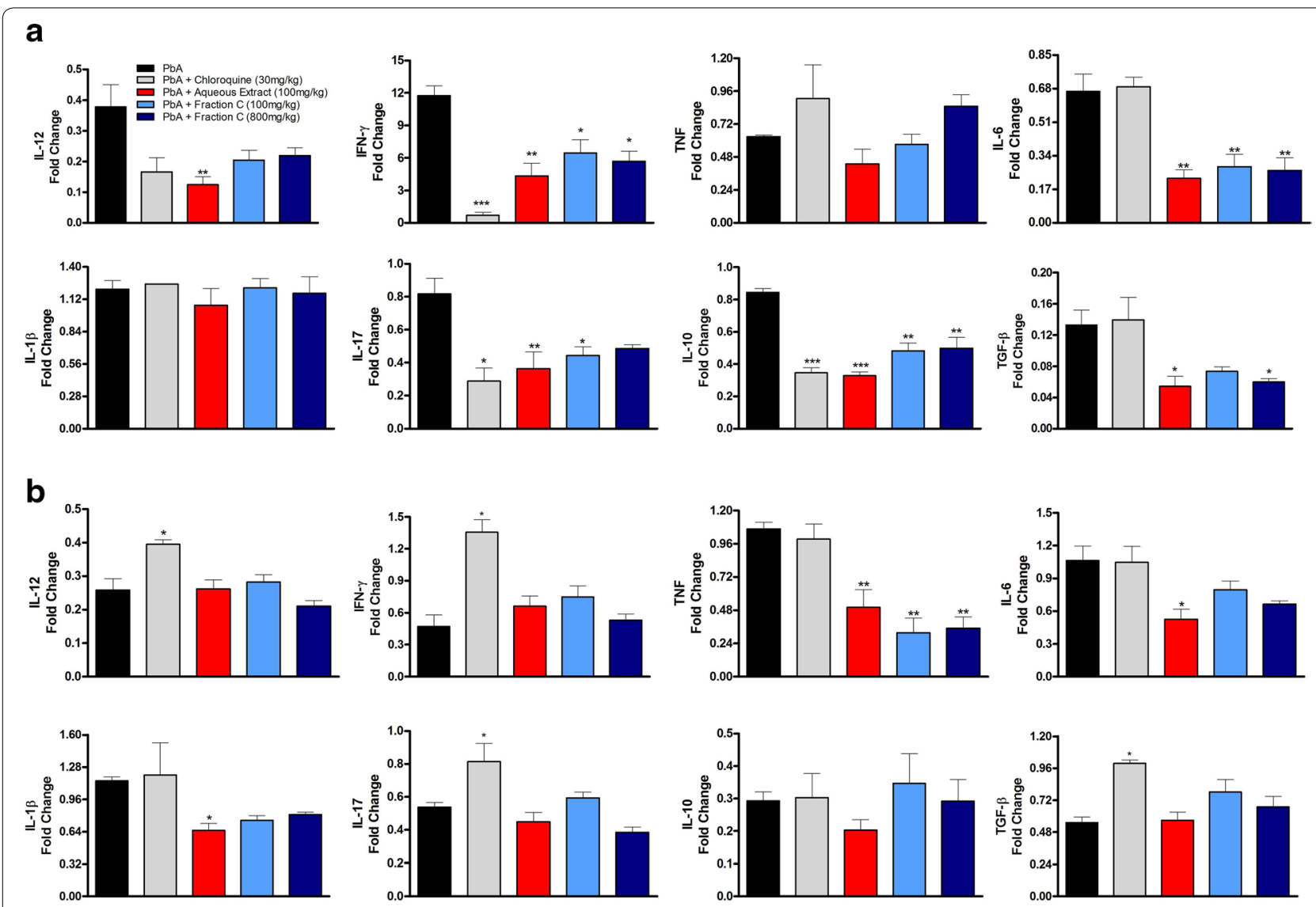

C

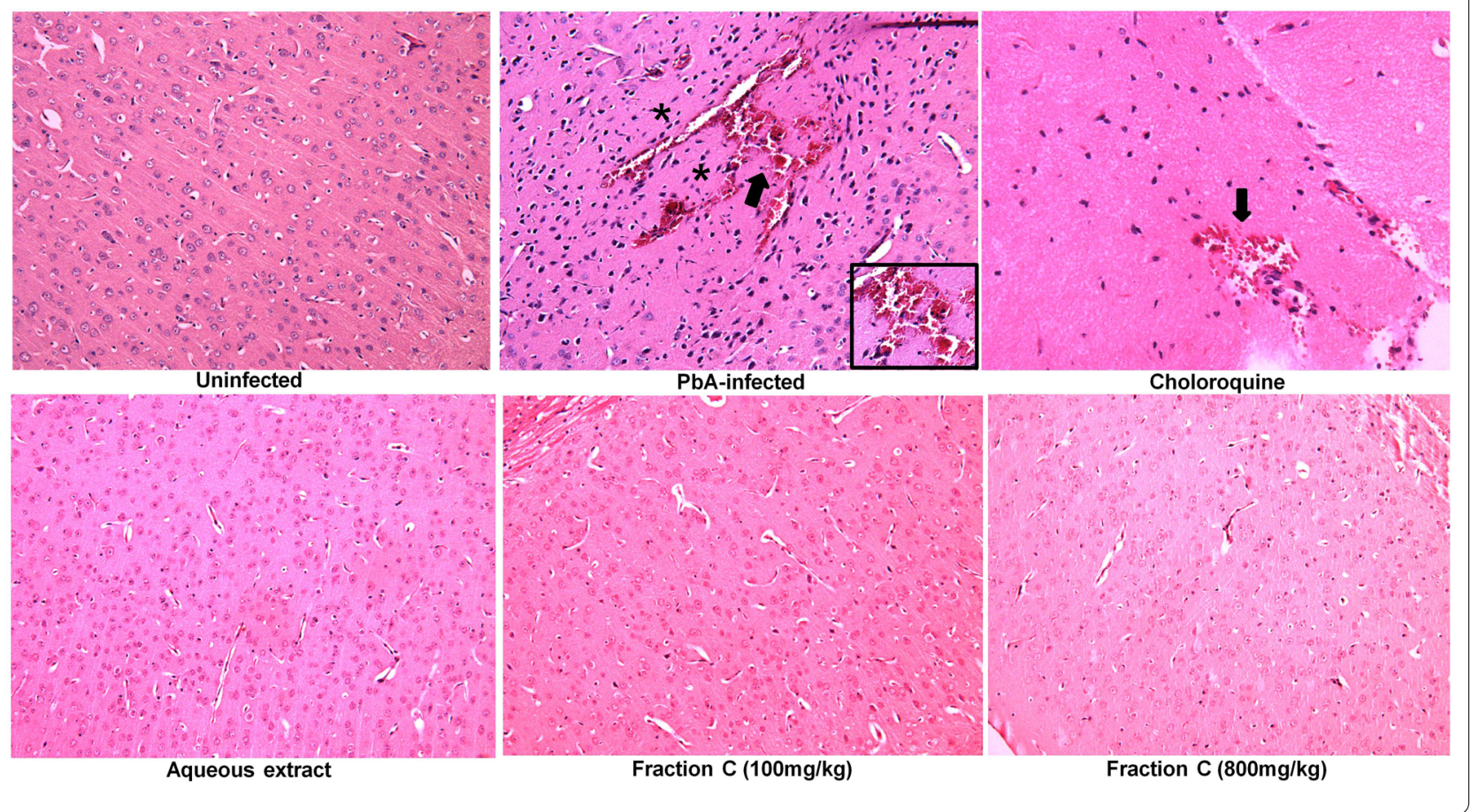


(See figure on previous page.)

Fig. 4 Administration of Agaricus blazei modulated cytokine expression in the spleen and brain and protected against CM development. C57BL/6 mice were pre-treated with $100 \mathrm{mg} / \mathrm{kg}$ of A. blazei extract, Fraction C (100 or $800 \mathrm{mg} / \mathrm{kg}$ ) or chloroquine (30 mg/kg) 3 days before infection, then infected with $10^{5}$ parasitized RBCs IP via, and treated until 5 dpi. Production of IL-12, IFN- $\gamma$, TNF, IL-6, IL-1 $\beta$, IL-17, IL-10 and TGF- $\beta$ in the spleen (a) and in the brain (b) in response to infection with P. berghei, measured at $5 \mathrm{dpi}$. Cytokines expression was normalized relative to that of uninfected controls for each mouse group. c Representative histological (H\&E) stained of cerebral cortex of mice, demonstrating severity of cerebral pathology on 5 dpi. It is observed cerebral cortex with normal histological aspect, containing healthy neurons in mice-uninfected and with extensive hemorrhagic area (arrow), surrounded by hyperchromatic and condensed neurons (asterisks) in P. berghei-infected animal. Small haemorrhagic focus (arrow) was detected in the brain of mice treated with chloroquine and cerebral parenchyma with normal histological aspect in mice treated with AbM aqueous extract or fraction C. Original magnification $\times 20$. Values are expressed as mean \pm SD of 5 mice per group. ${ }^{*} p<0.05$, ${ }^{* *} p<0.01$ and ${ }^{* * *} p<0.001$ compared to $P$. berghei-infected mice, ANOVA followed Bonferroni's test.

the A. blazei when compared to untreated-infected mice. There were no significant differences in IL-10, IL-12, IL-17, IFN- $\gamma$ and TGF- $\beta$ levels among the groups treated with $A$. blazei compared with untreated-infected mice (Fig. 4b). Increased levels of IL-12, IL-17, IFN- $\gamma$ and TGF- $\beta$ were observed in the brain of infected chloroquine-treated mice when compared with untreated infected mice. Taken together, these data suggest that $A$. blazei modulates cytokine production in the spleen and brain of infected mice (Fig. 4a, b).

Next, was examined whether $A$. blazei aqueous extract or fraction $C$ protected the brain of $P$. berghei-infected mice. Histological examination of brains from infected at 5 dpi revealed necrosis and hemorrhage in the cerebral cortex of untreated infected mice in contrast to A. blazeitreated infected mice. In chloroquine-treated mice there were areas of discrete hemorrhage (Fig. 4c).

\section{Anti-parasitic effect of Agaricus blazei in Plasmodium berghei}

To evaluate the direct effect of $A$. blazei on the parasite, $P$. berghei-infected red blood cells (RBCs) were pretreated with $A$. blazei aqueous extract or fraction $C$ for $1 \mathrm{~h}$ in vitro, and then was injected (i.p.) these treated RBCs into C57BL/6 mice. Mice injected with untreatedparasitized RBCs developed CM associated with ataxia, loss of grip strength, progressive paralysis, and coma succumbing between 8 and 11 dpi ( $80 \%)$ (Fig. 5). However, mice receiving $P$. berghei-infected RBCs treated with $A$. blazei aqueous extract or fraction $C$ displayed significantly parasitaemia reduction, no neurological dysfunction and significant increased survival (Fig. 5a, b). All groups displayed progressive decline in weight (Fig. 5c).

\section{Discussion}

The major findings of the current study can be summarized as follows: (1) A. blazei crude aqueous extract is effective in vitro and in vivo against P. berghei; (2) the activity resides mainly in a fraction of low MW compounds, denominated fraction $\mathrm{C}$; (3) fraction $\mathrm{C}$ delays lethality and protects from tissue damage. Indeed, fraction $\mathrm{C}$ is more effective than chloroquine in protecting against cerebral damage caused by the parasite; (4) incubation of the parasite with fraction $\mathrm{C}$ prior to infection causes partial protection from disease, suggesting the compound has direct effects on the parasite. Altogether, these findings suggest that molecules derived from A. blazei may be useful for the treatment of cerebral malaria.

Herein, it was reported that the administration of $A$. blazei extract to mice infected with $P$. berghei improved the development of CM. Both A. blazei aqueous extract and purified fraction $C$ have antioxidant activity, which may be responsible for their anti-parasitic and immunomodulatory effects. It has been demonstrated that $A$. blazei decreased lipid peroxidation in aged rats, demonstrating the capacity of the mixture to possess antioxidant effects in vivo [43]. A. blazei fraction C is a mixture of low MW compounds, including phenolic compounds, carbohydrates and peptides (Fig. 3). Other studies demonstrated that phenolic compounds and peptides may have immunomodulatory and/or anti-parasitic activity $[13,44]$. It was demonstrated that chemical analysis of $A$. blazei by phytochemical screening indicated the presence of glycoproteins, carbohydrates and tannins [20]. There were three phenolic compounds in A. blazei-gallic acid, syringic acid, and pyrogallol. These compounds possess pronounced antioxidant activity [45]. Additional studies will be required to elucidate the precise molecular composition of fraction $C$ that is responsible for anti-parasitic and immunomodulatory activity and whether the antioxidant activity does indeed contribute to the protection observed in vivo.

Oxidative stress has been linked to neurological and cognitive impairment in CM [46]. In the present study, we demonstrated that administration of $A$. blazei aqueous extract or fraction $C$ protected the brain from the damaging effects of this infection. In this regard, previous studies indicated that one activity of this mushroom is related with ROS scavenging and inhibition of lipid peroxidation $[4,12,47]$, which may be attributed, at least in part, to the phenolic compounds identified in A. blazei 

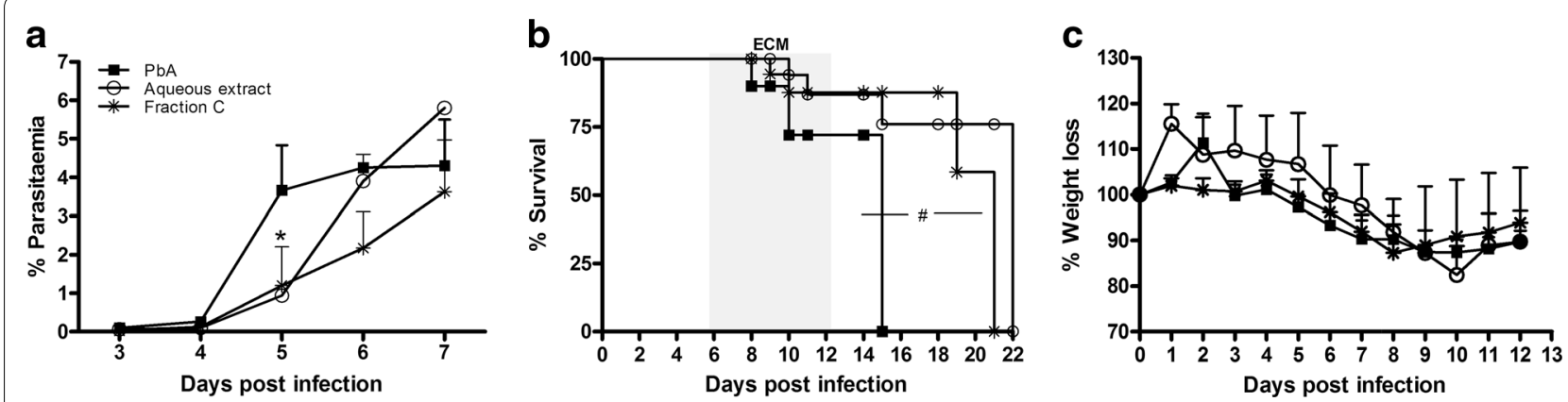

Fig. 5 Anti-parasitic effects of extract or fraction C of Agaricus blazei. a Parasitaemia, $\mathbf{b}$ survival and $\mathbf{c}$ body weight of mice infected with untreated pRBCs or treated during $1 \mathrm{~h}$ with A. blazei water extract or fraction C (500 $\mu \mathrm{g} / \mathrm{mL}$ ) in vitro. Neurologic signs of CM appeared on days $6-12$ (shaded area), with death occurring 24-48 h after onset. Parasitaemia and body weight values are expressed as mean \pm SD of 4 mice per group. ${ }^{\#} p<0.001$, log-rank test and * $p<0.05$, ANOVA followed Bonferroni's test.

[20]. Additionally, previous studies have demonstrated that $A$. blazei treatment was successful in improving the oxidative state of the brain of old rats and was capable of decrease levels of lipid peroxidation (TBARS) of old rats [43]. These results suggest that treatment with A. blazei can provide antioxidant activity to the brain in vivo.

It has been reported that antioxidants act by reducing ROS activity and inhibiting lipid peroxidation induced by Plasmodium in membrane of parasitized erythrocytes [48], suggesting that the observed anti-malarial effect may be related to the antioxidant activity of fraction C. This effect could be, in part, the result of iron chelation [3]. Anti-malarial drugs such as chloroquine, amodiaquine, primaquine and artemisinin are thought to kill the parasite by the induction of oxidative stress to eliminate the parasite [49]. However, this may also lead to ROS-induced damage to the host [49] as well as drug resistance $[50,51]$. In fact, chloroquine treatment, although effective in preventing mortality and reducing parasitaemia, did not prevent protection against brain damage $[46,52]$. Therefore, the antioxidant activity of fraction $\mathrm{C}$ may be important for the control of CM development in the experimental model of severe malaria.

In fact, the present study demonstrates that the administration of fraction $\mathrm{C}$ did not completely eliminate parasitaemia and weight loss despite significantly increasing survival of mice and protecting the brain. This is in agreement with studies by Ibrahim et al. [48] that using the antioxidant also failed to control the parasitaemia in mice infected with $P$. berghei. It is important to note that the elimination of parasitaemia is not always associated with improvement in clinical outcome either in humans or in animal models [29, 53, 54]. Similarly, while the increased production of cytokines in the early infection is important for parasite control it likely contributes to brain damage and cognitive dysfunction associated with CM.
Our results indicate that the administration of $A$. blazei in $P$. berghei-infected mice modified the profile of cytokines produced in the spleen compared to $P$. bergheiinfected or chloroquine-treated-infected mice. There was a reduction in the expression of TNF, IL- $1 \beta$ and IL- 6 in the brain of $A$. blazei aqueous extract-treated mice and of TNF in A. blazei fraction C-treated mice. The induction of these cytokines is associated with the expression of cell adhesion molecules, synthesis of other proinflammatory cytokines, apoptosis and activated phagocytes, all of which have been described in CM $[53,55,56]$. Studies by Lyke et al. [57] and Wunderlich et al. [58], demonstrated that high IL-6 levels were detected in children and mice that developed severe CM. Thus, the reduction levels of TNF, IL-1 $\beta$ and IL- 6 levels in $A$. blazei-treated mice could be related to brain protection and increase in survival (Figs. 4b, c, 2b, 3e), observed in the study.

Treatment with chloroquine resulted in an increased production of most proinflammatory cytokines in the brain (IL-12, IFN- $\gamma$ and IL-17) when compared to untreated-infected and $A$. blazei-treated infected mice. The elevation of TGF- $\beta$ in chloroquine-treated-infected mice may be associated with two possibilities: (1) inhibit/ diminish the proinflammatory response or (2) could be involved with the brain damage. These alterations (elevation of IL-12, IFN- $\gamma$, IL-17 and TGF- $\beta$ ) could explain, in part, the histopathologic changes observed in chloroquine-treated mice (Fig. 4c). In agreement, it have been previously reported in clinical and experimental studies a role for TGF- $\beta$ in malaria severity [59-61]. Taken together, our findings indicate a potential deleterious effect of chloroquine in the CNS not observed with $A$. blazei treatment. Other studies have shown that chloroquine was highly effective in decreasing parasitaemia and preventing mortality, but failed to prevent cognitive and behavioral functions altered in mice subjected to $\mathrm{CM}$. 
These studies suggest that anti-malarial treatment is not sufficient to protect against the consequences of $\mathrm{CM}$ and limiting the inflammatory damage in the brain is necessary in addition to anti-malarials to improve $\mathrm{CM}$ outcome $[46,52,62]$.

The injection of $P$. berghei-infected RBCs pre-incubated with $A$. blazei aqueous extract or fraction $\mathrm{C}$, was effective in preventing $\mathrm{CM}$. Although this incubation period was brief, it was effective and similar to previous findings with Leishmania species [18-20]. This result indicated a direct effect of $A$. blazei on parasite suggesting that it could contribute to control of parasite replication.

\section{Conclusion}

Treatment with the mushroom A. blazei is effective in preventing the development of experimental $\mathrm{CM}$ and may represent an alternative therapy in the treatment of malaria. Additional studies are needed to identification of compounds isolated from $A$. blazei fraction $\mathrm{C}$ responsible for the anti-malarial activity and establish its molecular mechanism of action. Moreover, the efficacy of the combination with other known anti-malarial drugs, and their long-term effect on outcome remains to be fully addressed. These studies may lead to novel therapeutic approaches both in the chemoprophylaxis and treatment of malaria.

\section{Additional files}

Additional file 1. Administration of Agaricus blazei aqueous extract at dose of $10 \mathrm{mg} / \mathrm{kg}$ did not confer protection during P. berghei ANKA infection. C57BL/6 mice received $10 \mathrm{mg} / \mathrm{kg}$ of $A$. blazei aqueous extract or chloroquine $(30 \mathrm{mg} / \mathrm{kg})$ three days before infection, then infected with $10^{5}$ pRBCs, and treated until 7 dpi. (A) Parasitaemia, (B) survival and (C) body weight loss of control P. berghei-infected mice and administered with chloroquine or aqueous extract of the A. blazei. Parasitaemia and body weight values are expressed as mean \pm SD of 5 mice per group. Log-rank test and ${ }^{* *} p<0.001$, ANOVA followed Bonferroni's test.

Additional file 2. Administration of $800 \mathrm{mg} / \mathrm{kg}$ of Agaricus blazei lyophilized extract resulted in significant survival of $P$. berghei ANKA-infected mice. (A) Parasitaemia and (B) survival of C57BL/6 mice that received $80 \mathrm{mg} / \mathrm{kg}$ or $800 \mathrm{mg} / \mathrm{kg}$ of A. blazei lyophilized extract or $30 \mathrm{mg} / \mathrm{kg}$ of chloroquine three days before infection, then infected with $10^{5} \mathrm{pRBCs}$, and treated until $7 \mathrm{dpi}$. Parasitaemia expressed as mean \pm SD of 5 mice per group. (A) ANOVA followed Bonferroni's test was applied and (B) \#p<0.001 Log-rank test.

Additional file 3. Transaminase determinations revealed no hepatic cytotoxic effects during A. blazei administration. C57BL/6 mice received $100 \mathrm{mg} / \mathrm{kg}$ of $A$. blazei extract, $100 \mathrm{mg} / \mathrm{kg}$ or $800 \mathrm{mg} / \mathrm{kg}$ of fraction C or $30 \mathrm{mg} / \mathrm{kg}$ of chloroquine three days before infection, then infected with $10^{5}$ parasitized RBCs IP via, and treated until $5 \mathrm{dpi}$. Transaminase determinations, (A) AST and (B) ALT were performed at 5 dpi in serum. Values are expressed as mean \pm SD of 5 mice per group and ANOVA followed Bonferroni's test was applied.

Additional file 4. There were no differences in parasitaemia and mortality between those mice treated with fraction $A$ and untreated mice during P. berghei ANKA infection. (A) Parasitaemia, (B) survival and (C) body weight loss of C57BL/6 mice that received $10 \mathrm{mg} / \mathrm{kg}$ of $A$. blazei fraction
A or $30 \mathrm{mg} / \mathrm{kg}$ of chloroquine three days before infection, then infected with $10^{5} \mathrm{pRBCs}$, and treated until $7 \mathrm{dpi}$. Parasitaemia and body weight values are expressed as mean \pm SD of 5 mice per group. Log-rank test and ${ }^{*} p<0.05,{ }^{* *} p<0.01$ and ${ }^{* *} p<0.001$, ANOVA followed Bonferroni's test.

Additional file 5. Different doses of fraction B were not effective in controlling the P. berghei ANKA infection. (A) Parasitaemia, (B) survival and (C) body weight loss of control P. berghei-infected mice and administered chloroquine or fraction $B(10,80$ and $800 \mathrm{mg} / \mathrm{kg})$. C57BL/6 mice were treated with $A$. blazei or chloroquine three days before infection, then infected with $10^{5} \mathrm{pRBCs}$, and treated until $7 \mathrm{dpi}$. Parasitaemia and body weight values are expressed as mean \pm SD of 5 mice per group. Log-rank test and ${ }^{*} p<0.05$, ${ }^{* *} p<0.01$ and ${ }^{* * *} p<0.001$, ANOVA followed Bonferroni's test.

Additional file 6. Fraction $C$ treated mice did not display clinical signs of $\mathrm{CM}$ and significant differences in haematrocrit during $P$. berghei infection. C57BL/6 mice were treated with fraction C of $A$. blazei or chloroquine three days before infection, then infected with $10^{5} \mathrm{pRBC}$, and treated until $7 \mathrm{dpi}$. (A) clinical signs of cerebral malaria assessed by the RMCBS score and (B) haematocrit assessed on $5^{\text {th }} \mathrm{dpi}$, normalized relative to that of uninfected controls for each mouse group. RMCBS score and haematocrit values were expressed as mean \pm SD of 5 mice per group. ${ }^{* * *} p<0.001$, ANOVA followed Bonferroni's test.

\section{Abbreviations}

ECM: experimental cerebral malaria; CM: cerebral malaria; MW: molecular weight; CNS: central nervous system; PbA: Plasmodium berghei ANKA.

\section{Authors' contributions}

$\mathrm{CHV}$ conceived and designed the study, performed experiments, analysed data and wrote the paper. FSM, WCBR, MMT and ALT conceived and designed the study, analysed data and wrote the paper, they were involved in all stages of the investigation. FB; AM; FGR; BOC; LE and DRRA were involved in the in vivo animal experimentation; EAS carried out processing, extraction, preparation and chemical characterization of extracts and Fractions for the study. BCS and MAR performed morphometric analysis, analysed and discussed data. HBT reviewed and discussed the experimental data. All authors have read and approved the manuscript.

\section{Author details}

1 Department of Biochemistry and Immunology, Institute of Biological Science, Federal University of Minas Gerais, Bloco O4, 190 Av. Antônio Carlos, 6627-Pampulha, Belo Horizonte, MG 31270-901, Brazil. ${ }^{2}$ Programme in Health Sciences: Infectious Diseases and Tropical Medicine, Medical School, Federal University of Minas Gerais, Belo Horizonte, MG, Brazil. ${ }^{3}$ Programa de Pós Graduação em Biologia de Vertebrados da Pontifícia Universidade Católica de Minas Gerais, Belo Horizonte, MG, Brazil. ${ }^{4}$ Department of Pathology, Institute of Biological Science, Federal University of Minas Gerais, Belo Horizonte, MG, Brazil. ${ }^{5}$ Department of Pathology and Department of Medicine, Albert Einstein College of Medicine, Bronx, NY, USA.

\section{Acknowledgements}

This work was made possible by funding from National Research CouncilCNPq (to FSM, MMT), Foundation for Research Support of Minas GeraisFAPEMIG (to FSM, MMT), Minasfungi of Brazil, NIH grant Al-076248 (to HBT) and of program Instituto Nacional de Ciência e Tecnologia (INCT) em Dengue (Brazil) [573876/2008-8]. We are also grateful to Dr. Claudio Marinho (University of São Paulo) for providing the P. berghei Anka-GFP (15cy1 clone) parasite. We thank Marcelo Matos Santoro (in memoriam) and Dr Carlos Alberto Pereira Tavares by contributions in discussions about the A. blazei, and Jamil Silvano de Oliveira who assisted in the extraction and characterization of $A$. blazei.

\section{Compliance with ethical guidelines}

\section{Competing interests}

The authors declare that they have no competing interests.

Received: 28 May 2015 Accepted: 3 August 2015

Published online: 11 August 2015 


\section{References}

1. Mizuno T, Zhuang C (1995) Maitake, Grifola frondosa, pharmacological effects. Food Rev Int 11:135-149

2. Firenzuoli F, Gori L, Lombardo G (2008) The medicinal mushroom Agaricus blazei Murrill: review of literature and pharmaco-toxicological problems. Evid Based Complement Alternat Med 5:3-15

3. Soares AA, de Souza CGM, Daniel FM, Ferrari GP, da Costa SMG, Peralta RM (2009) Antioxidant activity and total phenolic content of Agaricus brasiliensis (Agaricus blazei Murril) in two stages of maturity. Food Chem 112:775-781

4. Tsai S-Y, Tsai H-L, Mau J-L (2007) Antioxidant properties of Agaricus blazei, Agrocybe cylindracea, and Boletus edulis. Food Sci Technol 40:1392-1402

5. Turkoglu A, Duru ME, Mercan N, Kivrak I, Gezer K (2007) Antioxidant and antimicrobial activities of Laetiporus sulphureus (Bull.) Murrill. Food Chem 101:267-273

6. Bernardshaw S, Hetland G, Ellertsen LK, Tryggestad AM, Johnson E (2005) An extract of the medicinal mushroom Agaricus blazei Murill differentially stimulates production of pro-inflammatory cytokines in human monocytes and human vein endothelial cells in vitro. Inflammation 29:147-153

7. Hetland G, Johnson E, Lyberg T, Bernardshaw S, Tryggestad AMA, Grinde B (2008) Effects of the medicinal mushroom Agaricus blazei Murill on immunity, infection and cancer. Scand J Immunol 68:363-370

8. Delmanto RD, de Lima PL, Sugui MM, da Eira AF, Salvadori DM, Speit G et al (2001) Antimutagenic effect of Agaricus blazei Murrill mushroom on the genotoxicity induced by cyclophosphamide. Mutat Res 496:15-21

9. Gennari J, Gennari M, Felippe JR (2001) O Agaricus sylvaticus aumenta o número de células Natural Killer em pacientes com câncer. Revista de Medicina Complementar 7:42

10. Kobayashi H, Yoshida R, Kanada Y, Fukuda Y, Yagyu T, Inagaki K et al (2005) Suppressing effects of daily oral supplementation of beta-glucan extracted from Agaricus blazei Murill on spontaneous and peritoneal disseminated metastasis in mouse model. J Cancer Res Clin Oncol 131:527-538

11. Lin JG, Fan MJ, Tang NY, Yang JS, Hsia TC, Lin JJ et al (2012) An extract of Agaricus blazei Murill administered orally promotes immune responses in murine leukemia BALB/C mice in vivo. Integr Cancer Ther 11:29-36

12. Ellertsen LK, Hetland G (2009) An extract of the medicinal mushroom Agaricus blazei Murill can protect against allergy. Clin Mol Allergy 7:6

13. Hetland G, Johnson E, Lyberg T, Kvalheim G (2011) The mushroom Agaricus blazei Murill elicits medicinal effects on tumor, infection, allergy, and inflammation through its modulation of innate immunity and amelioration of Th1/Th2 imbalance and inflammation. Adv Pharmacol Sci 2011:157015

14. Forland DT, Johnson E, Saetre L, Lyberg T, Lygren I, Hetland G (2011) Effect of an extract based on the medicinal mushroom Agaricus blazei Murill on expression of cytokines and calprotectin in patients with ulcerative colitis and Crohn's disease. Scand J Immunol 73:66-75

15. Cardozo FT, Camelini CM, Mascarello A, Rossi MJ, Nunes RJ, Barardi CR et al (2011) Antiherpetic activity of a sulfated polysaccharide from Agaricus brasiliensis mycelia. Antiviral Res 92:108-114

16. Liu Y, Fukuwatari Y, Okumura K, Takeda K, Ishibashi K, Furukawa M et al (2008) Immunomodulating activity of Agaricus brasiliensis KA21 in mice and in human volunteers. Evid Based Complement Alternat Med 5:205-219

17. Oh TW, Kim YA, Jang WJ, Byeon Jl, Ryu CH, Kim JO et al (2010) Semipurified fractions from the submerged-culture broth of Agaricus blazei Murill reduce blood glucose levels in streptozotocin-induced diabetic rats. J Agric Food Chem 58:4113-4119

18. Valadares DG, Duarte MC, Oliveira JS, Chavez-Fumagalli MA, Martins VT, Costa LE et al (2011) Leishmanicidal activity of the Agaricus blazei Murill in different Leishmania species. Parasitol Int 60:357-363

19. Valadares DG, Duarte MC, Ramirez L, Chavez-Fumagalli MA, Lage PS, Martins VT et al (2012) Therapeutic efficacy induced by the oral administration of Agaricus blazei Murill against Leishmania amazonensis. Parasitol Res 111:1807-1816

20. Valadares DG, Duarte MC, Ramirez L, Chavez-Fumagalli MA, Martins VT, Costa LE et al (2012) Prophylactic or therapeutic administration of Agaricus blazei Murill is effective in treatment of murine visceral leishmaniasis. Exp Parasitol 132:228-236

21. WHO (2012) World Malaria Report 2012. World Health Organization, Geneva
22. Brant F, Miranda AS, Esper L, Rodrigues DH, Kangussu LM, Bonaventura D et al (2014) Role of the aryl hydrocarbon receptor in the immune response profile and development of pathology during Plasmodium berghei Anka infection. Infect Immun 82:3127-3140

23. Dorovini-Zis K, Schmidt K, Huynh H, Fu W, Whitten RO, Milner D et al (2011) The neuropathology of fatal cerebral malaria in malawian children. Am J Pathol 178:2146-2158

24. Neres R, Marinho CR, Goncalves LA, Catarino MB, Penha-Goncalves C (2008) Pregnancy outcome and placenta pathology in Plasmodium berghei ANKA infected mice reproduce the pathogenesis of severe malaria in pregnant women. PLoS One 3:e1608

25. WHO (2011) World Malaria Report 2011. World Health Organization, Geneva

26. Boivin MJ, Bangirana P, Byarugaba J, Opoka RO, Idro R, Jurek AM et al (2007) Cognitive impairment after cerebral malaria in children: a prospective study. Pediatrics 119:e360-e366

27. Hunt NH, Golenser J, Chan-Ling T, Parekh S, Rae C, Potter S et al (2006) Immunopathogenesis of cerebral malaria. Int J Parasitol 36:569-582

28. Idro R, Jenkins NE, Newton CR (2005) Pathogenesis, clinical features, and neurological outcome of cerebral malaria. Lancet Neurol 4:827-840

29. Kihara M, Carter JA, Newton CR (2006) The effect of Plasmodium falciparum on cognition: a systematic review. Trop Med Int Health 11:386-397

30. Sorimachi K, Akimoto K, Ikehara Y, Inafuku K, Okubo A, Yamazaki S (2001) Secretion of TNF- $\alpha$, IL- 8 and nitric oxide by macrophages activated with Agaricus blazei Murill fractions in vitro. Cell Struct Funct 26:103-108

31. Johnson E, Forland DT, Saetre L, Bernardshaw SV, Lyberg T, Hetland G (2009) Effect of an extract based on the medicinal mushroom Agaricus blazei murill on release of cytokines, chemokines and leukocyte growth factors in human blood ex vivo and in vivo. Scand J Immunol 69:242-250

32. Brand-Williams W, Cuvelier ME, Berset C (1995) Use of a free radical method to evaluate antioxidant activity. Food Sci Technol 28:25-30

33. Laemmli UK (1970) Cleavage of structural proteins during the assembly of the head of bacteriophage T4. Nature 227:680-685

34. de Miranda AS, Lacerda-Queiroz N, de Carvalho Vilela M, Rodrigues DH, Rachid MA, Quevedo J et al (2011) Anxiety-like behavior and proinflammatory cytokine levels in the brain of C57BL/6 mice infected with Plasmodium berghei (strain ANKA). Neurosci Lett 491:202-206

35. Lacerda-Queiroz N, Rodrigues DH, Vilela MC, Miranda AS, Amaral DC, Camargos ER et al (2010) Inflammatory changes in the central nervous system are associated with behavioral impairment in Plasmodium berghei (strain ANKA)-infected mice. Exp Parasitol 125:271-278

36. Carroll RW, Wainwright MS, Kim KY, Kidambi T, Gómez ND, Taylor T et al (2010) A rapid murine coma and behavior scale for quantitative assessment of murine cerebral malaria. PLoS One 5:e13124

37. González-Fandos E, Giménez M, Olarte C, Sanz S, Simón A (2000) Effect of packaging conditions on the growth of micro-organisms and the quality characteristics of fresh mushrooms (Agaricus bisporus) stored at inadequate temperatures. J Appl Microbiol 89:624-632

38. Sumiya T, Ikeda Y, Broadmeadow A, May K, Pritchard L, Horne C et al (2008) Himematsutake (Iwade Strain 101) extract (ABM-FD): genetic toxicology and a 3-month dietary toxicity study in rats. Food Chem Toxicol 46:1949-1959

39. Kuroiwa Y, Nishikawa A, Imazawa T, Kanki K, Kitamura Y, Umemura T et al (2005) Lack of subchronic toxicity of an aqueous extract of Agaricus blazei Murrill in F344 rats. Food Chem Toxicol 43:1047-1053

40. Lima CU, Souza VC, Morita MC, Chiarello MD, Karnikowski MG (2012) Agaricus blazei Murrill and inflammatory mediators in elderly women: a randomized clinical trial. Scand J Immunol 75:336-341

41. Hsu CH, Hwang KC, Chiang YH, Chou P (2008) The mushroom Agaricus blazei Murill extract normalizes liver function in patients with chronic hepatitis B. J Altern Complement Med 14:299-301

42. Lima CU, Cordova CO, Nóbrega Ode T, Funghetto SS, Karnikowski MG (2011) Does the Agaricus blazei Murill mushroom have properties that affect the immune system? An integrative review. J Med Food 14:2-8

43. de Sa-Nakanishi AB, Soares AA, de Oliveira AL, Comar JF, Peralta RM, Bracht A (2014) Effects of treating old rats with an aqueous Agaricus blazei extract on oxidative and functional parameters of the brain tissue and brain mitochondria. Oxid Med Cell Longev 2014:563179

44. Niu YC, Liu JC, Zhao XM, Wu XX (2009) A low molecular weight polysaccharide isolated from Agaricus blazei suppresses tumor growth and angiogenesis in vivo. Oncol Rep 21:145-152 
45. Carvajal AESS, Koehnlein EA, Soares AA, Eler GJ, Nakashima ATA, Bracht A et al (2012) Bioactives of fruiting bodies and submerged culture mycelia of Agaricus brasiliensis (A. blazei) and their antioxidant properties. Food Sci Technol 46:493-499

46. Reis PA, Comim CM, Hermani F, Silva B, Barichello T, Portella AC et al (2010) Cognitive dysfunction is sustained after rescue therapy in experimental cerebral malaria, and is reduced by additive antioxidant therapy. PLoS Pathog 6:e1000963

47. Elmastas M, Isildak O, Turkekul I, Temur N (2007) Determination of antioxidant activity and antioxidant compounds in wild edible mushrooms. J Food Compos Anal 20:337-345

48. Ibrahim MA, Zuwahu MM, Isah MB, Jatau ID, Aliyu AB, Umar IA (2012) Effects of vitamin $\mathrm{E}$ administration on Plasmodium berghei induced pathological changes and oxidative stress in mice. Trop Biomed 29:98-106

49. Becker K, Tilley L, Vennerstrom JL, Roberts D, Rogerson S, Ginsburg H (2004) Oxidative stress in malaria parasite-infected erythrocytes: hostparasite interactions. Int J Parasitol 34:163-189

50. Meierjohann S, Walter RD, Müller S (2002) Regulation of intracellular glutathione levels in erythrocytes infected with chloroquine-sensitive and chloroquine-resistant Plasmodium falciparum. Biochem J 368:761-768

51. Perez-Rosado J, Gervais GW, Ferrer-Rodríguez I, Peters W, Serrano AE (2002) Plasmodium berghei: analysis of the gamma-glutamylcysteine synthetase gene in drug-resistant lines. Exp Parasitol 101:175-182

52. Reis PA, Estato V, da Silva TI, d'Avila JC, Siqueira LD, Assis EF et al (2012) Statins decrease neuroinflammation and prevent cognitive impairment after cerebral malaria. PLoS Pathog 8:e1003099

53. Armah H, Wired EK, Dodoo AK, Adjei AA, Tettey Y, Gyasi R (2005) Cytokines and adhesion molecules expression in the brain in human cerebral malaria. Int J Environ Res Public Health 2:123-131

54. Dondorp AM, Nosten F, Yi P, Das D, Phyo AP, Tarning J et al (2009) Artemisinin resistance in Plasmodium falciparum malaria. N Engl J Med 361:455-467
55. Schofield L, Grau GE (2005) Immunological processes in malaria pathogenesis. Nat Rev Immunol 5:722-735

56. Shikani HJ, Freeman BD, Lisanti MP, Weiss LM, Tanowitz HB, Desruisseaux MS (2012) Cerebral malaria: we have come a long way. Am J Pathol 181:1484-1492

57. Lyke KE, Burges R, Cissoko Y, Sangare L, Dao M, Diarra I et al (2004) Serum levels of the proinflammatory cytokines interleukin-1 beta (IL-1beta), IL-6, IL-8, IL-10, tumor necrosis factor alpha, and IL-12(p70) in Malian children with severe Plasmodium falciparum malaria and matched uncomplicated malaria or healthy controls. Infect Immun 72:5630-5637

58. Wunderlich CM, Delic D, Behnke K, Meryk A, Strohle P, Chaurasia B et al (2012) Cutting edge: Inhibition of IL-6 trans-signaling protects from malaria-induced lethality in mice. J Immunol 188:4141-4144

59. Omer FM, Kurtzhals JA, Riley EM (2000) Maintaining the immunological balance in parasitic infections: a role for TGF- $\beta$ ? Parasitol Today 16:18-23

60. Walther $\mathrm{M}$, Tongren JE, Andrews L, Korbel D, King E, Fletcher $\mathrm{H}$ et al (2005) Upregulation of TGF-beta, FOXP3, and CD4+CD25+ regulatory T cells correlates with more rapid parasite growth in human malaria infection. Immunity 23:287-296

61. Wassmer SC, de Souza JB, Frere C, Candal FJ, Juhan-Vague I, Grau GE (2006) TGF-1 released from activated platelets can induce TNF-stimulated human brain endothelium apoptosis: a new mechanism for microvascular lesion during cerebral malaria. J Immunol 176:1180-1184

62. Dai M, Reznik SE, Spray DC, Weiss LM, Tanowitz HB, Gulinello M et al (2010) Persistent cognitive and motor deficits after successful antimalarial treatment in murine cerebral malaria. Microbes Infect 12:1198-1207

\section{Submit your next manuscript to BioMed Central and take full advantage of:}

- Convenient online submission

- Thorough peer review

- No space constraints or color figure charges

- Immediate publication on acceptance

- Inclusion in PubMed, CAS, Scopus and Google Scholar

- Research which is freely available for redistribution

Submit your manuscript at

www.biomedcentral.com/submit

C) Biomed Central 